\title{
Epidemiological characterization and risk factors associated with Leptospira infection in dogs from rural settlements in the semi-arid region of Northeast Brazil
}

\section{Caracterização epidemiológica e fatores de risco associados à infecção por Leptospira spp. em cães de assentamentos rurais na região semiárida do Nordeste do Brasil}

\author{
José Dêvede da Silva ${ }^{1}$; José Romero Alexandre Alves ${ }^{1}$; Diego Figueiredo Costa ${ }^{1}$; \\ Érico Luiz de Barros Correia ${ }^{1}$; Demmya Haryssam Menezes Melo²; Severino \\ Silvano dos Santos Higino ${ }^{3}$; Sergio Santos Azevedo ${ }^{3}$ Clebert José Alves ${ }^{3 *}$
}

\begin{abstract}
Rural settlements are defined as family-run agrarian spaces. Their purpose, based on public policies, is to strengthen family agriculture. They are peculiar environments that can predispose to the risk of diseases, especially zoonotic diseases, due to close natural contact with animals that can be sources of infection. The aim of this study was to determine the frequency of anti-Leptospira antibodies in dogs from rural settlements in the state of Paraíba, Northeast Brazil, and to identify the risk factors associated with infection. A total of 306 dogs were sampled and Leptospira screening was performed using the microscopic agglutination test. In all, 27 of $306(8.82 \%$; 95\% CI = 6.13-12.5\%) dogs were seropositive for Leptospira spp. The most frequent serotype was Pomona. Street access (odds ratio $=3.53, \mathrm{p}=0.012$ ) was indicated as a risk factor for infection. The results indicate that leptospirosis is present in dogs from rural settlements in the state of Paraíba, Northeast Brazil. This reinforces the need to limit contact between dogs and wild reservoirs and perform serological monitoring of swine. It also reinforces the need for implementation of control measures such as improvements in hygienic-sanitary conditions in the settlements, including the construction of pigsties away from homes, and the introduction of vaccination to reduce the occurrence of this disease, which will prevent transmission to humans and animals.
\end{abstract}

Key words: Zoonoses. Rural área. Risk factors. Serology.

\section{Resumo}

Os assentamentos rurais são definidos como espaços agrários de organização familiar, cuja finalidade é o fortalecimento da agricultura familiar a partir de políticas públicas. São ambientes peculiares que podem predispor ao risco de doenças, especialmente de caráter zoonótico, considerando naturalmente o convívio estreito com os animais, que de certo modo, podem atuar como fontes de infecção. O objetivo deste estudo foi determinar a frequência de anticorpos anti-Leptospira spp. em cães de assentamentos

1 Discentes de Doutorado, Programa de Pós-Graduação em Medicina Veterinária, UFCG, Patos, Brasil. E-mail: dvd.12@hotmail. com; j.romeroalves@bol.com.br; diegoveter@hotmail.com; erico_medvet@hotmail.com

2 Discente, Curso de Ciências Biológicas da Universidade Estadual da Paraíba, UEPB, Campina Grande, PB, Brasil. E-mail: demmyaharyssammm@gmail.com

3 Profs. Drs., Programa de Pós-Graduação em Medicina Veterinária, Universidade Federal de Campina Grande, UFCG, Patos, Brasil.E-mail: higinosss@gmail.com; sergio@vps.fmvz.usp.br; clebertja@uol.com.br

* Author for correspondence

Received: Aug. 08, 2016 Approved: May 11, 2017 
rurais do Estado da Paraíba, Nordeste do Brasil, bem como identificar os fatores de risco associados com a infecção. Foram utilizados 306 cães e o diagnóstico de Leptospira spp. realizados pela técnica de Soroaglutinação Microscópica (MAT). Foram identificados 27/306 (8,82\%; IC 95\% = 6,13 - 12,5\%) cães soropositivos para Leptospira spp. O sorotipo mais frequente foi o Pomona. A criação do tipo solto (Odds ratio $=3,53 ; \mathrm{p}=0,012)$ foi apontada como fator de risco para a infecção. Os resultados do presente estudo indicam que a leptospirose está presente em cães de áreas de assentamentos rurais do estado da Paraíba, Nordeste do Brasil. Isso reforça a necessidade de limitar o contato de cães com reservatórios silvestres, bem como fazer o monitoramento sorológico dos suínos e implantação de medidas de controle como melhorias nas condições higiênico-sanitárias nos assentamentos, destacandose a construção de pocilgas afastadas das residências e a introdução de vacinação com o intuito de reduzir a ocorrência dessa doença e, consequentemente, prevenir a transmissão da infecção aos seres humanos e animais.

Palavras-chave: Zoonoses. Zona rural. Fatores de risco. Sorologia.

\section{Introduction}

Leptospirosis is caused by bacteria of the genus Leptospira, which is widespread in tropical regions and can affect several animal species, including humans (ADLER; DE LA PEÑA MOCTEZUMA, 2010). Several species of animals can act as reservoirs of the disease, and infected dogs are a primary source of infection for humans (BATISTA et al., 1999, 2004), as they are able to eliminate Leptospira through the urine for long periods, thus exposing humans to infection (SCHULLER et al., 2015).

Various studies have demonstrated a large number of serotypes in wild animals. Silva et al. (2010) observed that opossums (Didelphis albiventris) and deer can be reservoirs of the Patoc, Autumnalis, Icterohaemorrhagiae, Andamana, and Canicola serotypes for domestic animals such as cattle, goats, sheep, pigs, horses, and dogs. The reservoirs of the Grippotyphosa serotype are wild animals such as raccoons and skunks (SALABERRY et al., 2011). In certain regions, different serotypes of Leptospira are prevalent and are associated with one or more maintenance hosts that act as reservoirs of the agent; reservoirs are usually wild species but may occasionally include companion and production animals (BOLIN, 1996). Dogs can be infected by a wide variety of serotypes; however, infection is more frequently associated with the presence of antibodies against the Canicola and Icterohaemorrhagiae serotypes (SCHULLER et al., 2015).

Leptospirosis is of considerable economic and public health importance, as it is widely disseminated, and there is a high rate of infectivity between domestic and wild animals. In dogs, this disease is a serious public health problem, not only due to the severity of its pathogenesis, but also as a potential element of contagion to humans due to close proximity (MASCOLLI et al., 2002; POLACHINO; FUJIMORI, 2015). Velineni et al. (2007) serologically assessed 55 humans with suspected leptospirosis using the microscopic agglutination test (MAT), and 50 of 55 serum samples tested positive for anti-Leptospira spp. antibodies. The predominant serotype was Icterohaemorrhagiae (68\%), followed by Australis $(22 \%)$ and Autumnalis (8\%). Although dogs are not the natural reservoir of those serotypes, they are usually identified in canines (ALVES et al., 2004; SCHULLER et al., 2015); thus, when infected, dogs can be a source of infection for other animals and for humans due to close contact.

In Brazil in recent years, the most common Leptospira serotypes identified in serological studies of canine species are Canicola, Copenhageni, 
Autumnalis, and Grippotyphosa (AZEVEDO et al., 2011; CASTRO et al., 2011; FERNANDES et al., 2013; LAVINSKY et al., 2012; MASCOLLI et al., 2016; PAZ et al., 2015).

Dogs are infected by direct contact with urine and tissues from infected animals, or indirectly by contact with water contaminated with the urine of infected animals (ADLER et al., 2011), and may be used as sentinel of the presence of Leptospira in the environment (GHNEIM et al., 2007). Canine leptospirosis displays varied clinical polymorphisms and must be considered by veterinary practitioners when establishing the differential diagnoses of major infectious diseases that affect this species (DE CASTRO et al., 2010). The most common signs observed in affected dogs are jaundice, hemorrhagic diathesis, and presentation of renal insufficiency (VAN DE MAELE et al., 2008).

The confirmation of leptospirosis can be performed using either clinical methods or laboratory data; the second is of paramount importance for diagnosis. Among laboratory methods, the MAT is the serological method recommended by the World Organization for Animal Health (OIE, 2012).

Rural settlements are areas designated for landless workers through government policies. They are peculiar environments that may predispose residents to the risk of diseases. Zoonotic diseases are a particular risk given the rural environment and the natural interaction with animals, which to a certain extent may be acting as sources of infection (GHNEIM et al., 2007; MASCOLLI et al., 2016). The present study is important because it increases understanding of the epidemiology of leptospirosis in dogs in rural settlements in Northeast Brazil, providing important information for the prevention and control of the disease in humans and in animal reservoirs.

Given the importance of leptospirosis in dogs and the importance of identifying the most frequent Leptospira serotypes in the region to better understand the epidemiology of the disease and establish public health policies directed to its control (GIANGASPERO et al., 2013), the aim of this study was to determine the frequency of anti-Leptospira spp. antibodies in dogs from rural settlements in the semiarid region of Paraíba State, Northeast Brazil, and identify the risk factors associated with infection.

\section{Materials and Methods}

This survey was conducted between March and October 2015 in 13 rural settlements distributed in the municipalities of São José de Espinharas, Santa Terezinha, São Mamede, São José do Bonfim, and Patos, located in the mesoregion of the Paraíba hinterland, a semiarid region of Northeast Brazil (Figure 1). 
Figure 1. A geographic representation of municipalit rom March to October 2015.

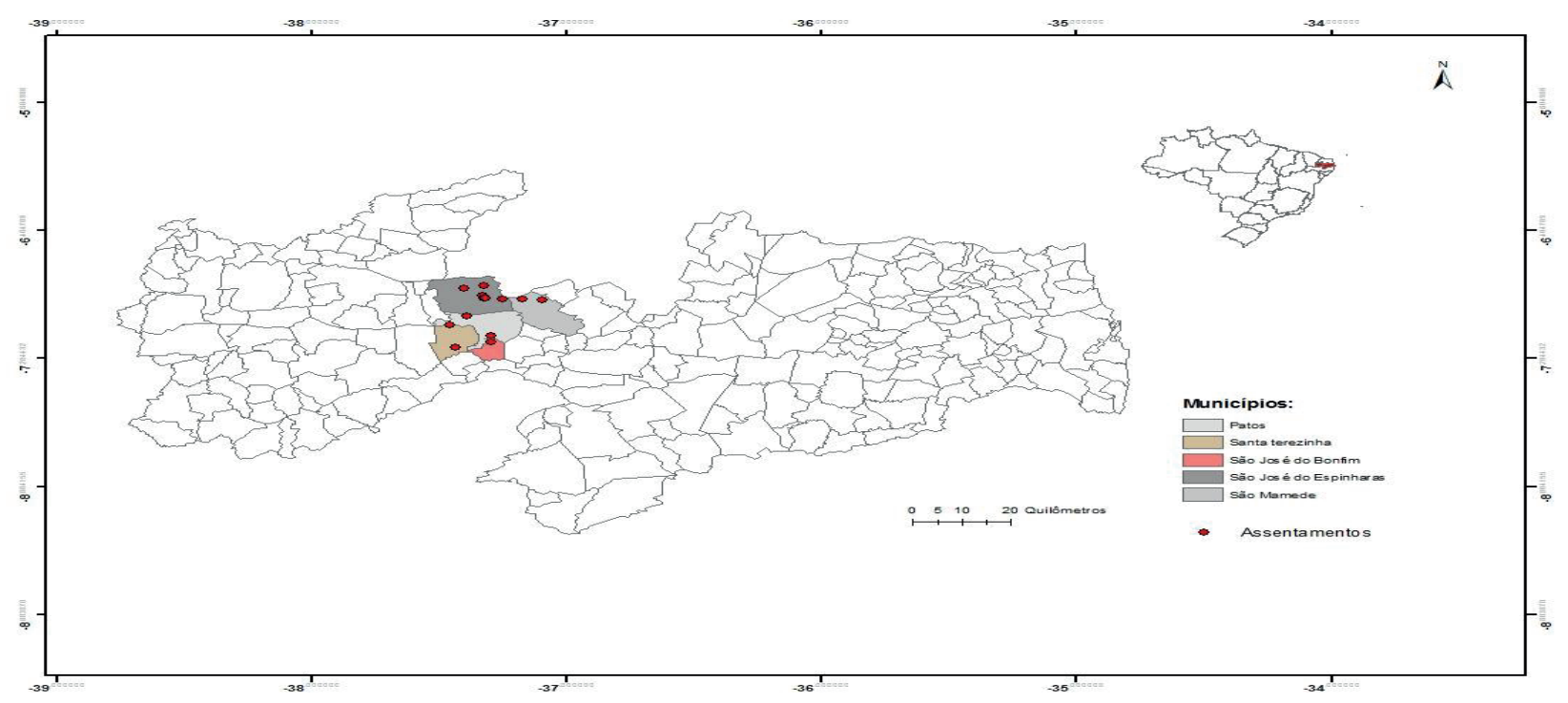

Municípios $=$ Municipalities.

Assentamentos $=$ Settlements.

The formula for simple random sampling was used to determine the minimum number of animals to be sampled (THRUSFIELD, 2007):

$$
\mathrm{n}=\frac{\mathrm{Z}^{2} \mathrm{P}_{\exp }\left(1-\mathrm{P}_{\exp }\right)}{\mathrm{d}^{2}}
$$

where $\mathrm{n}=$ sample size, $\mathrm{z}=$ value of the normal distribution for a confidence level of $95 \%, \mathrm{P}_{\exp }=$ expected prevalence, and $\mathrm{d}=$ statistical error

The parameters used were expected prevalence of $50 \%$ (maximization of sample), $95 \%$ confidence level, and absolute error of $6 \%$. According to these parameters, the minimum sample was 267 animals. However, 306 animals were sampled. We sampled all unvaccinated dogs of both sexes at least six months of age; dogs were different breeds and from 13 settlements. Sampling was conducted after owners gave consent by signing an informed consent form. After the immobilization of the animal, blood was collected by puncturing the cephalic, saphenous, or external jugular vein using a $5-\mathrm{mL}$ disposable syringe, and was deposited immediately into a plastic test tube without anticoagulant. After collection, the tubes were properly identified, placed in a polystyrene box with ice, and sent to the Laboratory for Communicable Diseases at the Centro de Saúde e Tecnologia Rural, Universidade Federal de Campina Grande (CSTR/UFCG), where serum was collected and transferred to $1.5-\mathrm{mL}$ microtubes and stored at $-20^{\circ} \mathrm{C}$ until analysis.

After prior training of the interviewers, an epidemiological questionnaire was completed by the dogs' owners to obtain data for risk factor analysis. The variables investigated and respective categories were as follows: level of education (illiterate, incomplete primary education, complete primary education, incomplete secondary education, complete secondary education, incomplete tertiary education, complete tertiary education); family income (up to two minimum wages, more than two to four minimum wages, between five and six minimum wages, more than six minimum wages); having some knowledge of canine leptospirosis (yes, no); washing hands before meals, after touching the animals (yes, no, sometimes, never); walking barefoot in the street or backyard (yes, 
no, sometimes, never); having rats in the house (yes, no); accumulation of garbage (yes, no); having water storage containers (yes, no); name of the animal; gender (male, female); age (six to 12 months, more than 12 and up to 24 months, more than 24 to 48 months, 4 to 6 years, above to 6 years); breed (mongrel, with defined breed, which breed); type of restraint (restrained, semi-loose, loose); diet (commercialdiet, food prepared at home, both); cases of abortions (yes, no); deliveries of stillbirths (yes, no); environment where the animal is kept (cement, earth, earth/cement); cleaning or disinfection of the site (yes, no); cleaning/disinfection frequency (daily, weekly, bi-weekly, monthly); contact with other animals (yes, no); if yes, which animals (horses, cats, wild animals, dogs, pigs, cattle, sheep, poultry); usually hunt with the animal (yes, no); the animal has contact with ponds or flooded areas (yes, no); the animal has received some vaccines (yes, no); if yes, which (rabies, antiviral, both, other); already has or has had ticks (yes, no); the animal has or has had fleas (yes, no); and physical examination of the animal.

The presence of anti-Leptospira antibodies was determined by the MAT (OIE, 2012), using as antigens the Leptospira biflexa serotypes Andamana and Patoc; Leptospira interrogans serotypes Australis, Copenhageni, Bataviae, Bratislava, Canicola, Grippotyphosa, Hardjoprajitno, Pomona, Pyrogenes, Icterohaemorrhagiae, Hebdomadis, Wolffi, and Butembo; Leptospira borgpetersenii serotypes Autumnalis, Castellonis, Hardjobovis, Javanica, and Tarassovi; Leptospira santarosai serotypes Guaricura and Shermani; Leptospira kirschneri serotype Cynopteri; and Leptospira noguchii serotype Panama. The strains were ceded by the Laboratory of Veterinary Bacteriology of Fluminense Federal University (UFF) and from the Pasteur Institute, France. All samples with agglutinating activity at a dilution of 1:100 were considered positive (OIE, 2014). Positive samples were titrated serially at a ratio of two, and the antibody titer was the reciprocal of the highest dilution that presented $50 \%$ of agglutinations. The highest titer achieved was used to identify the infecting serotype.

The results of the diagnostic tests and the information from the questionnaires were stored in a database using Microsoft Excel (Microsoft Corp., Redmond, WA, USA). The analysis of risk factors was initially performed using univariate analysis, in which each independent variable was submitted for analysis of the association with the dependent variable (the result of the serology); those with $p$ $\leq 0.2$ as determined by the chi-square test (ZAR, 1999) were selected for multivariate analysis using logistic regression (HOSMER; LEMESHOW, 2000). The fit of the model was verified with the Hosmer and Lemeshow test; $p=0.05$ indicated satisfactory adjustment. The level of significance in the multiple analyses was 5\%. All analyses were performed using SPSS Statistics for Windows Version 20.0 (IBM Corp., Armonk, NY, USA).

The project was assessed and approved by the Research Ethics Committee (CEP) of the Health and Rural Technology Center at the CSTR/UFCG and was filed under project no. 324/2015.

\section{Results}

Of 306 canine serum samples analyzed, 27 were seropositive (titer $\geq 1: 100$ ) for Leptospira spp., resulting in an average frequency of $8.82 \%$ (95\% CI $=6.13-12.5 \%$ ) (Table 1). Of these, 9.1\% (21/232) were male dogs and $8.1 \%(6 / 74)$ were females. The titer ranged from $1: 100$ to $1: 400$; serotypes detected were Pomona (44.4\%), Bataviae (11.1\%), Copenhageni, Australis, and Bratislava (7.4\%), and Icterohaemorrhagiae, Autumnalis, Tarassovi, Grippotyphosa, Djasimane, Canicola (3.7\%) (Table 2); a higher frequency of seropositivity in was observed in dogs from the Aroeira settlement (22.22\%), followed by the Oziel Alves (15.78\%) and Tubarão (15.15\%) settlements (Table 1). Table 3 shows the results of the univariate analysis with 
the variables most associated with seropositivity ( $\mathrm{p} \quad$ risk factor for seropositivity (odds ratio $=3.53 ; 95 \%$ $\leq 0.2$ ). In the final logistic regression model, being $\quad \mathrm{CI}=1.32-9.46 ; \mathrm{p}=0.012$ ).

loose or having street access was determined to be a

Table 1. Frequency of anti-Leptospira antibodies according to settlement and serotype detected in dogs; sampling was conducted in the semiarid region of Paraíba State, from March to October 2015.

\begin{tabular}{cccc}
\hline Settlement & Total no. of dogs & Positive (\%) & Serotypes detected \\
\hline Tiradentes & 14 & $0(0)$ & - \\
Cachoeira & 10 & $1(3.70)$ & Pomona \\
Oziel Alves & 19 & $3(11.11)$ & Pomona, Bratislava \\
Maria Paz & 20 & $0(0)$ & - \\
Nova Espinharas & 19 & $0(0)$ & Bratislava \\
Nova Santana & 24 & $1(3.70)$ & Icterohaemorrhagiae, Autumnalis \\
Dom Expedito & 28 & $2(7.40)$ & Djasiman, Copenhageni, Pomona, Australis \\
& & & Pomona \\
Aroeira & 18 & $4(14.81)$ & Pomona, Australis, Bataviae \\
Tubarão & 33 & $5(18.51)$ & $1(3.70)$ \\
Mundo Novo & 27 & $0(0)$ & Copenhageni, Pomona, Grippotyphosa, Canicola \\
Saco do Monte & 12 & $5(18.51)$ & \\
Campo Comprido & 45 & $5(18.51)$ & \\
Patativa & 37 & $27(99.95)$ & \\
Total & 306 & &
\end{tabular}

Table 2. Serotypes of more prevalent Leptospira spp. and their titrations in dogs from settlements in Paraíba State, Northeast Brazil, from March to October 2015.

\begin{tabular}{|c|c|c|c|c|c|}
\hline \multirow{2}{*}{ Serotypes } & \multicolumn{4}{|c|}{ Titration } & \multirow[t]{2}{*}{ Total $(\%$} \\
\hline & 100 & 200 & 400 & 800 & \\
\hline Pomona & 3 & 7 & 2 & - & $12(44.4)$ \\
\hline Bataviae & 2 & 1 & - & - & $3(11.1)$ \\
\hline Australis & - & 2 & - & - & $2(7.4)$ \\
\hline Bratislava & 1 & - & 1 & - & $2(7.4)$ \\
\hline Copenhageni & - & 1 & 1 & - & $2(7.4)$ \\
\hline Autumnalis & 1 & - & - & - & $1(3.7)$ \\
\hline Icterohaemorrhagiae & - & 1 & - & - & $1(3.7)$ \\
\hline Canicola & - & 1 & - & - & $1(3.7)$ \\
\hline Grippotyphosa & - & 1 & - & - & $1(3.7)$ \\
\hline Tarassovi & - & 1 & - & - & $1(3.7)$ \\
\hline Djasiman & - & 1 & - & - & $1(3.7)$ \\
\hline
\end{tabular}


Table 3. Univariate analysis of risk factors associated with leptospirosis in dogs from settlements in Paraíba State between March and October 2015.

\begin{tabular}{ccccc}
\hline Variable & Category & $\begin{array}{c}\text { Total no. of } \\
\text { Individuals }\end{array}$ & Positive (\%) & p \\
\hline Have knowledge of leptospirosis & No & 266 & $21(7.9)$ & \\
& Yes & 40 & $6(15)$ & \\
Contact with pigs & No & 233 & $17(7.3)$ & \\
& Yes & 73 & $10(13.7)$ & 0.148 \\
Contact with ponds & No & 141 & $8(36.2)$ & \\
& Yes & 165 & $19(40.6)$ & 0.104 \\
Municipality & São José de Espinharas & 46 & $6(13)$ & \\
& São Mamede & 106 & $5(4.7)$ & \\
& Santa Terezinha & 33 & $5(15.2)$ & \\
& São José do Bonfim & 82 & $10(12.2)$ & \\
& & & $1(2.6)$ & 0.094 \\
Cistern & Ducks & 39 & $1(2.3)$ & \\
& No & 44 & $26(9.9)$ & 0.147 \\
Breeding & Yes & 262 & $6(14.3)$ & \\
& Home Kept & 42 & $14(6.2)$ & \\
& Semi-loose & 227 & $7(18.9)$ & 0.016 \\
\hline
\end{tabular}

\section{Discussion}

The frequency of seropositive animals $(8.82 \%)$ identified in this study was similar to that observed by Fernandes et al. (2013) in studies conducted in the state of Rio Grande do Norte and by Lavinsky et al. (2012) in Bahia, who reported frequencies of $6.8 \%$ and $7.1 \%$, respectively. Higher results were obtained by Paz et al. (2015) in Pará, PA; Castro et al. (2011) in the municipality of Uberlândia, MG; Azevedo et al. (2011) in Patos, PB; Lemos et al. (2010) in the municipality of Aracajú, SE; Aguiar et al. (2007) in the municipality of Monte Negro, RO; and Batista et al. (2005) in the city of Campina Grande, PB; who observed, respectively, $17 \%, 28.4 \%, 19.74 \%, 37 \%, 27.3 \%$, and $21.4 \%$ seropositivity. These differences in positivity can be explained by the variety of factors that influence the occurrence of leptospirosis, particularly with regard to the topography; region; temperature; humidity; rainfall; wild reservoirs such as Brazilian guinea pigs, foxes, and skunks; domestic reservoirs; and other environmental factors (ALVES et al., 2000). The low frequency of seropositive animals in this study may be justified by the difference in canine populations studied and the lower rainfall observed in the period and region studied. According to Costa et al. (2001), an increase in leptospirosis cases occurs with an increase of rainfall.

From 2011 to 2015, the Northeast region suffered from lower rainfall than expected. In 2015, rainfall did not reach $550 \mathrm{~mm}$ in the cities studied (AESA, 2015), which was below or at the limit (500 to 550 $\mathrm{mm}$ ) necessary for survival and spread of Leptospira in the semiarid region (ALVES et al., 1996). Thus, the long drought can be considered responsible for the low seroreactivity observed in the dogs in this study. 
The frequency between the settlements from the different municipalities ranged from $0 \%$ to $18.51 \%$. Although all were located in the semiarid region, this difference may be related to the characteristics of the microclimate and environmental factors, such as the presence of ponds, dams, streams, and land topography, and also to the control measures implemented. In addition, the structural conditions of the settlements may have helped determine the occurrence of the disease, given that there were marked differences in sanitary conditions among them, such as sanitary sewage, paving, and piped water. These factors, alone or in combination, may have influenced the frequency of leptospirosis in the animals analyzed.

The Pomona serotype, most frequent in this study, is considered incidental in dogs. This serotype was also found by Batista et al. (2004) and Alves et al. (2000) in dogs, but it normally circulates in swine (FIGUEIREDO et al., 2013). Its occurrence as the most prevalent variant in the canine population from the settlements indicates contact between canine and swine populations, which occurs frequently in the various settlements where a number of the settlers interviewed (44/184) have small pig farms. As swine are important reservoirs of the Pomona serotype, the serological results suggest that they may function as reservoirs of this serotype for canines and eventually for humans and other animal species in these nesting areas. The Pomona serotype was associated with an outbreak of leptospirosis in humans in the Province of Ciego de Avila, Cuba (HERNÁNDEZ et al., 1999).

The Bataviae serotype was the second most frequent in this study, followed by Australis, Copenhageni, Icterohaemorrhagiae, Grippotyphosa, and Autumnalis, which strengthens the hypothesis that dogs are infected from wild animals, as the region has wild fauna and microclimates favorable to the survival and spread of Leptospira. Spickler and Leedom Larson (2013) pointed to the importance of the rodent population in the transmission of the disease, as synanthropic rodents such as the rat (Rattus norvegicus) are common hosts of Icterohaemorrhagiae and Copenhageni serotypes and wild rodents are common hosts of Autumnalis (FAINE et al., 1999). Consequently, it is possible that the serotypes found are related to the occurrence of these hosts in the environment, as most respondents (139/184) reported the presence of these rodents on their properties, and 42/184 hunted wild animals. Alves et al. (2004) found that $8.95 \%$ (17/190) of hunting dogs in the state of Paraíba tested positive for anti-Leptospira agglutinins. The most frequently detected serotype was Autumnalis, suggesting involvement of wild animals in the transmission cycle of the disease. Although occurring at low frequency, Canicola and Icterohaemorrhagiae are known to be the most commonly found serotypes in this species (SCHULLER et al., 2015); as dogs can eliminate these serotypes for long periods in their urine, the test results alerted health officials to the risk of infection of humans (FAINE et al., 1999; TESSEROLLI et al., 2008).

Being loose or having street access was considered a risk factor for infection by Leptospira spp. in dogs. A seropositivity rate of $18.9 \%$ was observed in loose animals, while dogs kept at home or in semi-loose conditions displayed $14.3 \%$ and $6.2 \%$ seropositivity, respectively. Similar results were obtained by Mascolli et al. (2016) in a study conducted in dogs of the tourist resort of Ibiúna, São Paulo, which found that the type of establishment where the animal remains loose was a risk factor for the occurrence of leptospirosis. In a study conducted in dogs in the city of Botucatu, São Paulo, Silva et al. (2006) showed that dogs who had access to the street were more seroreactive. Although this study found that allowing animals to remain loose was a risk factor, it was found that semi-loose management prevailed under the conditions of rural settlements, where the dogs were restrained in the yard, but were also released by the owner or used when hunting, a situation that could be a risk condition for this type of environment. However, in the statistical analysis, this type of management was not considered to 
be a risk factor, even after finding 14 (51.8\%) seropositive dogs.

The settlements studied presented environmental and socio-cultural characteristics that provided a favorable environment for the maintenance of the agent. These characteristics include the following: houses near forests, lack of basic sanitation, accumulation of garbage, poor housing conditions, accumulation of organic matter, and the joint breeding of several animal species, including pigs. Although without significant influence in the risk analysis in this study, breeding may have influenced the higher frequency of the Pomona serotype. Another aspect that increases the risk of infection is the practice of hunting wild animals, which exposes dogs and humans to contaminated environments. Alves et al. (2004) found a leptospirosis frequency of $8.95 \%$ (17/190) in hunting dogs in Paraíba. Lastly, the peculiar situation regarding the period of intense drought should be considered, which may have favored the approach of animals, especially wild animals, to the peridomicile in search of water and food, thus causing the contamination of the environment through urine. However, as discussed earlier, drought restricts Leptospira survival.

\section{Conclusion}

The results of this study indicate that leptospirosis is present in dogs from rural settlement areas in Paraíba, Northeast Brazil. This reinforces the need to limit the contact of dogs with wild reservoirs, to serologically monitor swine, and to deploy control measures such as improvements to hygienic-sanitary conditions in the settlements, construct pigsties away from residences, and introduce vaccination to reduce Leptospira occurrence, which will prevent its transmission to humans and other animals.

\section{Acknowledgements}

We would like to thank the Cooperative for the Provision of Technical Services in Agrarian Reform of Paraíba LTDA (COOPTERA) for the assignment of the technical team for sample collection and the Coordination for Improvement of Higher Education Personnel (CAPES) for financial support.

\section{References}

ADLER, B.; LA PEÑA MOCTEZUMA, A. de. Leptospira and leptospirosis. VeterinaryMicrobiology, Amsterdã, v. 140, n. 3, p. 287-296, 2010.

ADLER, B.; LO, M. SEEMANN, T.; MURRAYB, G. L. Pathogenesis of leptospirosis: the influence of genomics. Veterinary Microbiology, Amsterdã, v. 153, n. 1, p. 7381, 2011.

AGÊNCIA EXECUTIVA DE GESTÃO DAS ÁGUAS DO ESTADO DA PARAÍBA. - AESA. Monitoramento Pluviométrico. João Pessoa: Governo do Estado da Paraíba, 2015. Disponível em: $<$ http://site2.aesa.pb.gov. $\mathrm{br} /$ aesa/sort.do?layoutCollection $=0$ \&layoutCollection Property $=\&$ layoutCollectionState $=17 \&$ pagerPage $=4>$. Acesso 14 jan. 2016.

AGUIAR, D. M.; CAVALCANTE, G. T.; MARVULO, M. F. V.; SILVA, J. C. R.; PINTER, A.; VASCONCELLOS, S. A.; MORAIS, Z. M.; LABRUNA, M. B.; CAMARGO, L. M. A.; GENNARI, S. M.; Fatores de risco associados à ocorrência de anticorpos anti-Leptospira spp. em cães do município de Monte Negro, Rondônia, Amazônia Ocidental Brasileira. Arquivo Brasileiro de Medicina Veterinária e Zootecnia, Belo Horizonte, v. 59, n. 1, p. 7076, 2007.

ALVES, C. J.; ANDRADE, J. S. L.; VASCONCELLOS, S. A.; MORAIS, Z.M.; AZEVEDO, S. S.; SANTOS, F. A. Avaliação dos níveis de aglutininas anti-leptospira em cães no município de Patos - PB, Brasil. Revista Brasileira de Ciência Veterinária, Niterói, v. 7, n. 1, p. 17-21, 2000.

ALVES, C. J.; CLEMENTINO, I. J.; OLIVEIRA, A. G. F.; FREITAS, T. D.; VASCONCELLOS, S. A.; MORAIS, Z. M. Avaliação dos níveis de aglutininas antileptospira em cães de caça na Paraíba, Brasil. Revista Brasileira de Ciência Veterinária, Niterói, v. 11, n. 1-2, p. 68-73, 2004.

ALVES, C. J.; VASCONCELlOS, S. A.; CAMARGO, C. R. A.; MORAIS, Z. M. Influência dos fatores ambientais sobre a proporção de caprinos soro-reatores para a leptospirose em cinco centros de criação do Estado da Paraíba, Brasil. Arquivos do Instituto Biológico, São Paulo, v. 63, n. 2, p. 11-19, 1996.

AZEVEDO, S. S.; FERNANDES, A. R. F.; QUEIROGA, I. M. B. N.; ALVES, C. J.; MORAIS, Z. M.; SANTOS, C. 
S. A. B.; VASCONCELLOS, S. A. Ocorrência e fatores de risco associados à leptospirose em cães atendidos em hospital veterinário no semiárido paraibano. Brazilian Journal of Veterinary Research and Animal Science, São Paulo, v. 48, n. 2, p. 161-166, 2011.

BATISTA, C. S. A.; AZEVEDO, S. S.; ALVES, C. J.; VASCONCELLOS, S. A.; MORAIS, Z. M.; CLEMENTINO, I. J.; LIMA, F. S.; NETO, J. O. A. Soroprevalência de leptospirose em cães errantes da cidade de Patos, Estado da Paraíba, Brasil. Brazilian Journal of Veterinary Research and Animal Science, São Paulo, v. 41, n. 2, p. 131-136, 2004.

BATISTA, C. S.A.;AZEVEDO, S. S.; VASCONCELLOS, S. A.; MORAIS, Z. M.; CLEMENTINO, I. J.; ALVES, F. A. L.; LIMA, F. S.; ARÚJO NETO, J. O. Soroprevalência e fatores de risco para a leptospirose em cães de Campina Grande, Paraíba. Arquivo Brasileiro de Medicina Veterinária e Zootecnia, Belo Horizonte, v. 57, n. 2, p. 179-185, 2005.

BOLIN, C. A. Diagnosis of leptospirosis: a reemerging disease of companion animals. Seminars in Veterinary Medicine and Surgery-Small Animal, Philadelphia, v. 11, n. 3, p. 166-171, 1996.

CASTRO, J. R.; SALABERRY, S. R. S.; SOUZA, M. A.; LIMA-RIBEIRO, A. M. C. Sorovares de Leptospira spp. predominantes em exames sorológicos de caninos e humanos no município de Uberlândia, Estado de Minas Gerais. Revista da Sociedade Brasileira de Medicina Tropical, Uberaba, v. 44, n. 2, p. 217-222, 2011.

COSTA, E.; COSTA, Y. A.; LOPES, A. A.; SACRAMENTO, E.; BINA, J. C. Formas graves de leptospirose: aspectos clínicos, demográficos e ambientais. Revista da Sociedade Brasileira de Medicina Tropical, Uberaba, v. 34, n. 3, p. 261-67, 2001.

DE CASTRO, J. R.; SALABERRY, S. R. S.; CARDOSO NETO, A. B.; ÁVILA, D. F. de.; SOUZA, M. A. de.; LIMA-RIBEIRO, A. M. C. Leptospirose canina- Revisão de literatura. Publicações em Medicina Veterinária e Zootecnia, Londrina, v. 4, n. 31, p. 25-32, 2010.

FAINE, S.; ADLER, B.; BOLIN, C.; PEROLAT, P. Leptospiraand leptospirosis. 2. ed. Melbourne: MediSci, 1999. $272 \mathrm{p}$.

FERNANDES, A. R. F.; FERNANDES, A. G.; ARAÚJO, V. J. A.; HIGINO, S. S. S.; SILVA, M. L. C. R.; ALVES, C. J.; AZEVEDO, S. S. Soroepidemiologia da leptospirose canina na região metropolitana de Natal, estado do Rio Grande do Norte. Brazilian Journal of Veterinary Research and Animal Science, São Paulo, v. 50, n. 3, p. 226-232, 2013.
FIGUEIREDO, I. L.; HIGINO, S. S. S.; ALVES, C. J.; DEL FAVA, C.; CARRETERO, M. E.; AZEVEDO, S. S. Interrelação entre frequência de anticorpos antiLeptospira spp. e exames histopatológicos (Hematoxilinaeosina e Warthin-Starry) em suínos abatidos no semiárido paraibano. Arquivos do Instituto Biológico, São Paulo, v. 80 , n. 1, p. 27-34, 2013.

GHNEIM, G. S.; VIERS, J. H.; CHOMEL, B. B.; KASS, P. H.; DESCOLLONGES, D. A.; JOHNSON, M. L. Use of a case-control study and geographic information systems to determine environmental and demographic risk factors for canine leptospirosis. Veterinary Research, Londres, v. 38, n. 1, p. 37-50, 2007.

GIANGASPERO, M.; BONFINI, B.; ORUSA, R.; SAVINI, G.; OSAWA, T.; HARASAWA, R. Epidemiological survey for Toxoplasma gondii, Chlamydia psittaci var. ovis, Mycobacterium paratuberculosis, Coxiellaburnetii,Brucella spp., Leptospirosis, and orf virus among sheep from northern districts of Japan. The Journal of Veterinary Medical Science, Tokyo, v. 75, n. 5, p. 679-684, 2013.

HERNÁNDEZ, M. S.; SÁCHEZ, R. M.; FERNÁNDEZ, P. E. P.; GARCÍA, I. V.; FLEITES, F. B.; SIBELLO, A. S. Brotes de leptospirosis humana en la provincia de Ciego de Ávila, Cuba. Revista da Sociedade Brasileira de Medicina Tropical, Uberaba, v. 32, n. 1, p. 13-18, 1999.

HOSMER, D. W.; LEMESHOW, S. Applied logistic regression. John Wiley and Sons, New York, 2000. 375 p.

LAVINSKY, M. O.; SAID, R. A; STRENZEL, G. M. R.; LANGONI, H. Seroprevalence of anti-Leptospira spp. antibodies in dogs in Bahia, Brazil. Preventive Veterinary Medicine, Amsterdã, v. 106, n. 1, p. 79-84, 2012.

LEMOS, J. P.; MELO, C. B.; VIEGAS, S. A. R. A. Análise sorológica de Leptospiraspp. em cães errantes no Município de Aracaju. Revista Científica Eletrônica de Medicina Veterinária, Garça, v. 14, n. 14, p. 1-16, 2010.

MASCOLLI, R.; PINHEIRO, S. R.; VASCONCELLOS, S. A.; FERREIRA, F.; MORAIS, Z. M.; PINTO, C. O.; SUCUPIRA, M. C. A.; DIAS, R. A.; MIRAGLIA, F.; CORTEZ, A.; SILVEIRA DA COSTA, S.; TABATA, R.; MARCONDES, A. G. Inquérito sorológico para leptospirose em cães do município de Santana de Parnaíba, São Paulo, utilizando a campanha de vacinação anti-rábica do ano de 1999. Arquivos do Instituto Biológico, São Paulo, v. 69, n. 2, p. 25-32, 2002.

MASCOLLI, R.; SOTO, F. R. M.; BERNARDI, F.; ITO, F. H.; PINHEIRO, S. R.; GUILLOUX, A. G. A.; AZEVEDO, S. S.; FERNANDES, A. R. F.; KEID, L. B.; MORAIS, Z. M.; SOUZA, G. O.; VASCONCELOS, S. A. Prevalência e fatores de risco para a leptospirose 
e brucelose na população canina da Estância Turística de Ibiúna, São Paulo, Brasil. Arquivos do Instituto Biológico, São Paulo, v. 83, n. 1, p. 1-7, 2016.

PAZ, G. S.; ROCHA, K. S.; LIMA, M. S.; JORGE, E. M.; PANTOJA, J. C. F.; MORAES, C. C. G.; LANGONI, H. Seroprevalence for brucellosis and leptospirosis in dogs from Belém and Castanhal, State of Pará, Brazil. Acta Amazonica, Manaus, v. 45, n. 3, p. 265-270, 2015.

POLACHINO, C. O.; FUJIMORI, K. Canine and human leptospirosis, a possible conjunctival transmission in the Municipality of São Paulo, São Paulo State, Brazil. Revista Pan-Amazônica de Saúde, Pará, v. 6, n. 1, p. 5965, 2015.

SALABERRY, R. S. S.; CASTRO, V.; NASSAR, A. F. C.; CASTRO, J. R.; GUIMARÃES, E. C.; LIMARIBEIRO, A. M. C. Seroprevalence and risk factors of antibodies against leptospira spp. in ovines from Uberlândia municipality, Minas Gerais state, Brazil. Brazilian Journal of Microbiology, São Paulo, v. 42, n. 4, p. 1427-1433, 2011.

SCHULLER, S.; FRANCEY, T.; HARTMANN, K.; HUGONNARD, M.; KOHN, B.; NALLY, J. E.; SYKES, J. European consensus statement on leptospirosis in dogs and cats. The Journal of small animal practice, New Jersey, v. 56, n. 3, p. 159-79, 2015.

SILVA, F. J.; MATHIAS, L. A.; MAGAJEVSKI, F. S.; WERTHER, K.; ASSIS, N. A.; GIRIO, R. J. S. Anticorpos contra Leptospira spp. em animais domésticos e silvestres presentes no campus universitário da FCAV, Unesp, Jaboticabal/SP. Ars Veterinária, Jaboticabal, v. 26, n. 1, p. $17-25,2010$.

SILVA, W. B.; SIMÕES, L. B.; LOPES, A. L. S.; PADOVANI, C. R.; LANGONI, H.; MODOLO, J.R. Avaliação de fatores de risco de cães sororreagentes à Leptospira spp. e sua distribuição espacial, em área territorial urbana. Brazilian Jornal of Veterinary
Research and Animal Science, São Paulo, v. 43, n. 6, p. 783-792, 2006.

SPICKLER, A. R.; LEEDOM LARSON, K. R. Leptospirosis. The Center for Food Security \& Public Health. Ames: Iowa State University, 2013. Available at: $<$ http://www.cfsph.iastate.edu/DiseaseInfo/ factsheets. php>. Accessed at: 14 abr. 2016.

TESSEROLLI, G. L.; ALBERTI, J. V. A.; BERGAMASCHI, C.; FAYZANO, L.; AGOTTANI, J. V. B. Principais sorovares de leptopirose canina em Curitiba, Paraná. Publicações em Medicina Veterinária e Zootecnia, Londrina, v. 2, n. 21, p. 1-8, 2008.

THRUSFIELD, M. Veterinary epidemiology. 3. ed. Oxford: Blackwell Science, 2007. 624 p.

VAN DE MAELE, I; CLAUS, A.; HAESEBROUCK, F.; DAMINET, S. Leptospirosis in dogs: a review with emphasis on clinical aspects. The Veterinary Record. Londres, v. 163, n. 14, p. 409-413, 2008.

VELINENI, A.; ASUTHKAR, S.; UMABALA, P.; LAKSHMI, V.; SRITHARAN, M. Serological evaluation of leptospirosis in Hyderabad, Andhra Pradesh: A retrospective hospital-based study. Journal of Medical Microbiology, Londres, v. 25, n. 1, p. 24-27. 2007.

WORLD ORGANIZATION FOR ANIMAL HEALTH OIE. Manual of diagnostic tests and vaccines for terrestrial animals. Paris: World Organization for Animal Health, 2014. Available at: $<$ http://www.oie.int/fileadmin/Home/ eng/Health_standards/tahm/2.01.12_LEPTO.pdf, 2014>. Accessed at:14 abr. 2017.

Manual of diagnostic tests and vaccines for terrestrial animals. $6^{\text {th }}$ ed. Paris: World Organization for Animal Health, 2012. 1343 p.

ZAR, J. H. Biostatistical analysis. $4^{\text {rd }}$ ed. Prentice-Hall, New Jersey, 1999. 663 p. 
